\title{
Landslide mapping for susceptibility \& hazard assessment: N. York Moors, UK
}

\author{
H. Jordan, D. Boon, C. Dashwood, T. Dijkstra, K. Freeborough, P. Hobbs, G. Jenkins, K. Lee, \\ C. Pennington \& H. Reeves
}

British Geological Survey, Nottingham, United Kingdom

\begin{abstract}
The British Geological Survey (BGS) has developed a multi-stage methodology for landslide mapping by augmenting traditional mapping techniques with new geospatial technologies. This allows better characterisation and understanding of the country's landslides: an essential requirement for landslide susceptibility modelling, risk assessment and resilient infrastructure planning. The BGS methodology has most recently been applied to the North York Moors National Park in northern England, UK: an area with steep slopes, landslide-prone lithologies and an exposed coastal section but few recorded landslide events. Over 550 landslides have now been identified and data on the characteristics and mechanisms of these have been used to inform hazard assessments and susceptibility modelling research including the National Landslide Database, the National Landslide Domains Map and the National Geohazard Assessment.
\end{abstract}

\section{INTRODUCTION}

On an international scale the UK appears as a relatively 'low-risk' environment for landslides. However, abundant relict landslides, failure-susceptible lithologies, vulnerable coastal sections, ageing infrastructure slopes and changing weather conditions mean that landslides have a significant impact on economy and society. The UK has one of the highest recorded landslide densities in Europe (Van Den Eeckhaut \& Hervás 2012, Gunther et al. 2013) and Gibson et al. (2013) estimate that $£ 57$ billion worth of housing stock is at risk from landslide activity (using December 2010 average purchase prices). 2012 was an especially landslide-prone year, with 165 failures causing 3 fatalities, 8 injuries and 3 train derailments, amongst numerous other damage (Pennington \& Harrison 2013).

In order to better characterise and understand the UK's landslides, the British Geological Survey (BGS) has developed a multi-stage methodology to map and catalogue existing slope instability across the country. This uses traditional mapping techniques combined with 3-D aerial photograph interpretation, variable-perspective 3-D topographic visualisation and digital data capture (Evans et al. 2013), applied through a series of strategic (national and regional-scale), repeat (recurring local) and responsive (rapid-deployment, site specific) surveys. The landslide inventory data gathered during these surveys is used by the BGS to enhance the National Landslide Database (NLD) and the National Landslide Domains Map (NLDM). The data is also used to inform the National Geohazard Assessment (NGA) which investigates the susceptibility of the UK landmass to landslide activity, alongside a suite of other geohazards. This information is designed to aid stakeholders, including civil engineers, government planners, insurance companies, utility operators and home buyers, aiming to reduce injury and loss of life from landslides and allowing resilient planning.

This paper describes the application of the BGS landslide mapping methodology to the area of the North York Moors National Park in northern England, UK. A region which, despite the presence of steep slopes, landslideprone lithologies and an exposed coastal section of more than $35 \mathrm{~km}$, previously had few recorded landslides. The new landslide inventory for the National Park is presented below along with detailed case studies of selected landslides. Implications for hazard assessment and susceptibility modelling derived from the identified failure characteristics and mechanisms are also discussed. 


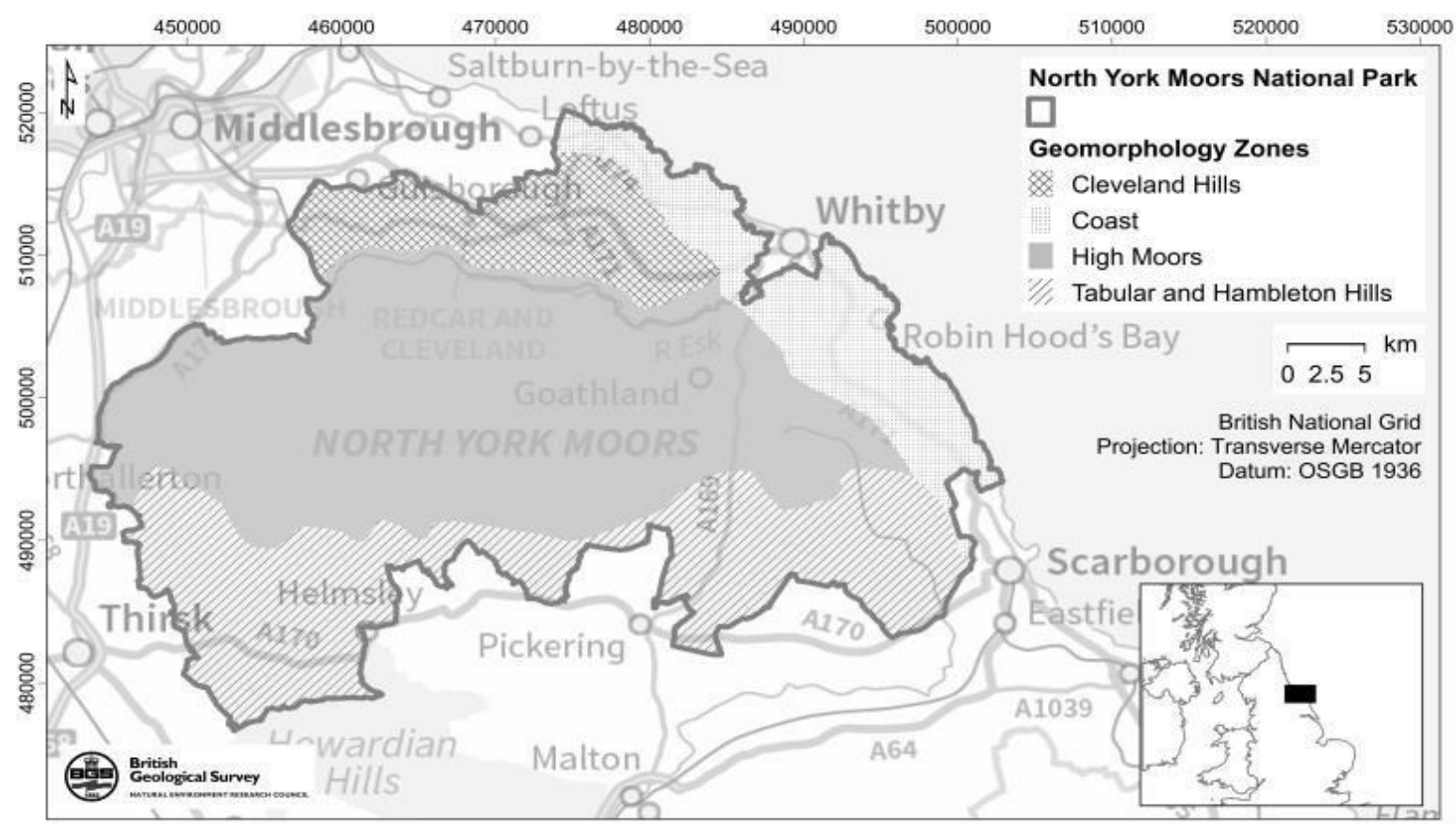

Figure 1. Geomorphology zones of the North York Moors National Park. Contains Ordnance Survey data (C) Crown Copyright and database rights 2015 .

\subsection{The North York Moors National Park}

The North York Moors National Park study area lies within the county of North Yorkshire in north-east England, UK (Figure 1). The National Park covers an area of $1441 \mathrm{~km}^{2}$ and includes 4 main geomorphological zones (BGS 1992, 1998):

1. The High Moors - forming the central part of the study area, this open heather moorland (maximum elevation $454 \mathrm{mOD}$ ) slopes gently southwards and is intersected by north-south trending incised Ushaped valleys. The western margin of this zone is defined by a steep escarpment.

2. Cleveland Hills - the northern portion of the study area encompasses gently undulating hills which reach a maximum elevation of $329 \mathrm{mOD}$ and slope gently east. The zone is bounded to the south by the steeply-incised River Esk and to the north-east by a steep escarpment.

3. Tabular and Hambleton Hills - lying to the south of the study area, these hills (maximum elevation 374 mOD) form a varied landscape of wooded dales and pasture land and are separated from the high moors by a low escarpment.

4. Coast - the eastern edge of the study area (excepting the area around Whitby which lies outside of the park) is defined by an elevated coastal plain sloping gently to steep cliffs intersected by sheltered embayments. Cliff elevations generally decrease southwards from approximately 200 mOD to 30 mOD.

Now a largely rural district, the North York Moors was once the centre of abundant mining and quarrying activity. Mineral extraction still occurs at the Boulby Potash Mine and a planning application has been submitted for a mineral transport tunnel across the area.

The geology of the National Park is characterised by Middle Jurassic sandstones, mudstones and limestones lying beneath the High Moors and the Cleveland Hills (Table 1). These are intersected towards the east by the Palaeogene igneous ArmathwaiteCleveland Dyke. To the south are clays, limestones and sandstones of the Late Jurassic. Early Jurassic mudstones and siltstones outcrop in incised valleys of the High Moors, along the River Esk, in the escarpment which bounds the National Park to the north-west and along the coast. 
Table 1. The stratigraphy of the North York Moors National Park (after BGS 1992, 1998). Note Quaternary deposits are not necessarily listed in order of superposition.

\begin{tabular}{|c|c|c|}
\hline Period & Formation/ superficial unit & Description \\
\hline \multirow[b]{11}{*}{ 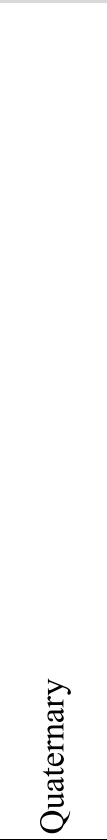 } & Alluvium (ALV) & Clay, silt \\
\hline & Tufa (TUFA) & Calcareous silt \\
\hline & Peat (PEAT) & Peat \\
\hline & Talus (TALUS) & Sand, gravel, boulders \\
\hline & $\begin{array}{l}\text { River Terrace Deposits } \\
\text { (undifferentiated) (RTDU) }\end{array}$ & Sand, gravel, clay \\
\hline & Lacustrine deposits (LDE) & Silt, sand, clay \\
\hline & $\begin{array}{l}\text { Beach \& Tidal Flat Deposits } \\
\text { (BTFU) }\end{array}$ & Sand \\
\hline & Head (HEAD) & Clay, silt, sand, gravel \\
\hline & Loess (LOESS) & Silt \\
\hline & $\begin{array}{l}\text { Devensian Till including } \\
\text { parts of Vale of York } \\
\text { Formation (TILLD) } \\
\end{array}$ & $\begin{array}{l}\text { Clay, silt, with sands, } \\
\text { gravel \& boulders }\end{array}$ \\
\hline & $\begin{array}{l}\text { Devensian Glaciofluvial } \\
\text { Deposits \& Devensian } \\
\text { Deposits including parts of } \\
\text { Vale of York Formation } \\
\text { (GFDU) }\end{array}$ & Sand, gravel \\
\hline 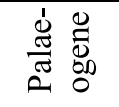 & $\begin{array}{l}\text { Armathwaite-Cleveland } \\
\text { Dyke (CAD) }\end{array}$ & Basaltic andesite \\
\hline \multirow[t]{14}{*}{ 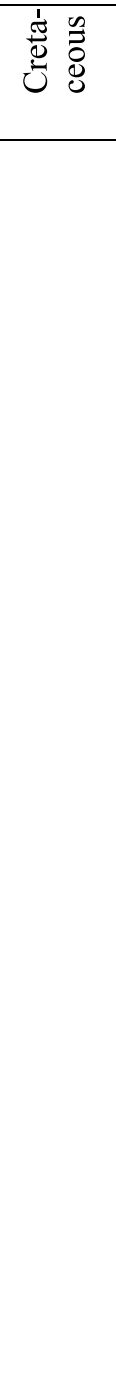 } & $\begin{array}{l}\text { Speeton Clay Formation } \\
\text { (SPC) }\end{array}$ & $\begin{array}{l}\text { Clay with limestone \& } \\
\text { phosphate concretions }\end{array}$ \\
\hline & $\begin{array}{l}\text { Kimmeridge Clay Formation } \\
(\mathrm{KC})\end{array}$ & $\begin{array}{l}\text { Mudstone, bituminous } \\
\text { in parts }\end{array}$ \\
\hline & $\begin{array}{l}\text { Upper Calcareous Grit } \\
\text { Formation (UCG) } \\
\end{array}$ & Siltstone \& sandstone \\
\hline & $\begin{array}{l}\text { Coralline Oolite Formation } \\
(\mathrm{COO})\end{array}$ & $\begin{array}{l}\text { Oolidal limestone \& } \\
\text { sandstone }\end{array}$ \\
\hline & $\begin{array}{l}\text { Lower Calcareous Grit } \\
\text { Formation (LCG) }\end{array}$ & Sandstone \\
\hline & $\begin{array}{l}\text { Oxford Clay Formation } \\
(\mathrm{OXC})\end{array}$ & Mudstone \\
\hline & Osgodby Formation (OSB) & Sandstone \\
\hline & $\begin{array}{l}\text { Cornbrash Formation \& } \\
\text { Cayton Clay Formation } \\
\text { (undifferentiated) (CBCA) }\end{array}$ & Limestone \& mudstone \\
\hline & Scalby Formation (SCY) & $\begin{array}{l}\text { Mudstone, siltstone \& } \\
\text { sandstone }\end{array}$ \\
\hline & $\begin{array}{l}\text { Scarborough Formation } \\
(\mathrm{SCR})\end{array}$ & $\begin{array}{l}\text { Limestone, sandstone } \\
\& \text { mudstone }\end{array}$ \\
\hline & $\begin{array}{l}\text { Cloughton Formation } \\
(\mathrm{CLH})\end{array}$ & $\begin{array}{l}\text { Sandstone \& mudstone } \\
\text { with some ironstone \& } \\
\text { limestone }\end{array}$ \\
\hline & $\begin{array}{l}\text { Eller Beck Formation } \\
\text { (EBB) }\end{array}$ & $\begin{array}{l}\text { Mudstone \& sandstone } \\
\text { with some ironstone \& } \\
\text { limestone }\end{array}$ \\
\hline & Saltwick Formation (SWK) & $\begin{array}{l}\text { Sandstone \& mudstone } \\
\text { with some coal }\end{array}$ \\
\hline & Dogger Formation (DGR) & $\begin{array}{l}\text { Ferruginous and } \\
\text { calcareous sandstone }\end{array}$ \\
\hline 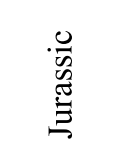 & $\begin{array}{l}\text { Blea Wyke Sandstone } \\
\text { Formation }(\mathrm{BW})\end{array}$ & Sandstone \\
\hline
\end{tabular}

\begin{tabular}{lll}
\hline Period & Formation/ superficial unit & Description \\
\hline $\begin{array}{l}\text { Whitby Mudstone Formation } \\
\text { (WhM) }\end{array}$ & $\begin{array}{l}\text { Mudstone \& siltstone } \\
\text { with beds of calcareous } \\
\text { nodules \& jet }\end{array}$ \\
\hline $\begin{array}{l}\text { Cleveland } \\
\text { Formation (CDI) }\end{array}$ & Ironstone & $\begin{array}{l}\text { Mudstone, siltstone \& } \\
\text { sandstone with } \\
\text { ironstone beds }\end{array}$ \\
\hline $\begin{array}{l}\text { Staithes Sandstone Formation } \\
\text { (STA) }\end{array}$ & $\begin{array}{l}\text { Sandy siltstone \& } \\
\text { sandstone }\end{array}$ \\
\hline Redcar Mudstone Formation & $\begin{array}{l}\text { Mudstone \& siltstone } \\
\text { with carbonate nodules } \\
\text { (RMU) }\end{array}$ \\
& $\begin{array}{l}\text { and thin beds of } \\
\text { limestone \& sandstone }\end{array}$ \\
\hline
\end{tabular}




\section{METHODOLOGY}

The BGS landslide mapping methodology detailed in Evans et al. (2013) was used in order to undertake a strategic survey of the North York Moors National Park study area. Actions specific to the North York Moors National Park study area are outlined in the following. Prior to the commencement of the field survey 3-D aerial photograph interpretation using SOCET for ArcGIS software was undertaken to identify potential landslide features. Orthorectified colour aerial photographs were obtained for the study area. Georeferenced ESRI ArcGIS polygons were digitised for areas of potential landslides and attributed with likely landslide type. These were augmented by variable-perspective 3-D topographic visualization of the study area using Geovisionary ${ }^{\mathrm{TM}}$ software. BGS geological maps, historical topographic maps, OS Open Source topographic data, NextMap Digital Elevation data and existing literature were also consulted in order to build up a picture of the area's slope instability history.

Field investigation was undertaken by members of the BGS Landslide Team in May, October and November 2010; May and October 2011 and October 2012. By visiting the area in the early summer and autumn masking of the landslide features by heavy vegetation cover was reduced and the grouse nesting season in the high moors avoided. Meanwhile, the use of a three year period for field investigation was designed to help reduce the 'snap-shot' nature of landslide mapping campaigns. Ruggedised tablet PCs carrying BGS•SIGMAmobile software allowed at-site manipulation of the landslide polygons digitised prior to field validation. The bespoke BGS landslide proforma was also populated at-site to aid systematic recording of attributed point data for input into the NLD (Foster et al. 2012, Pennington et al. 2015) and delineation of landslide domains and sub-domains for the NLDM. Digital photographs (and associated locational metadata) of the landslides were also captured for population of the BGS photograph repository, GeoScenic (geoscenic.bgs.ac.uk/assetbank/action/viewHome).

\section{RESULTS \& DISCUSSION}

\subsection{North York Moors National Park Landslide Map And Inventory}

The BGS strategic landslide survey has revealed 556 landslides in the North York Moors National Park study area (Figure 2). These cover a total area of $45.8 \mathrm{~km}^{2}$ (3.2\% of the National Park) and are most frequent in the High Moors (42.1\% of the total landslides in the park area) and Tabular and Hambleton Hills (26.9 \%) geomorphological zones (Table 2). The Cleveland Hills contain the fewest landslides at $7.3 \%$ of the study area total. When landslide area rather than landslide number is taken into account (Table 2) these values change most markedly for the Tabular and Hambleton Hills and Coast areas although the overall ranking of the zones by degree to which they are affected by landslides remains the same. The Tabular and Hambleton Hills area now accounts for $41.6 \%$ of the total landslide area in the National Park (versus $26.9 \%$ of landslide number). The opposite trend is seen in the Coast zone which accounts for $5.4 \%$ of landslide area and $23.6 \%$ of landslide number. This suggests an increased incidence of larger landslides in the Tabular and Hambleton Hills zone and smaller landslides at the coast. 


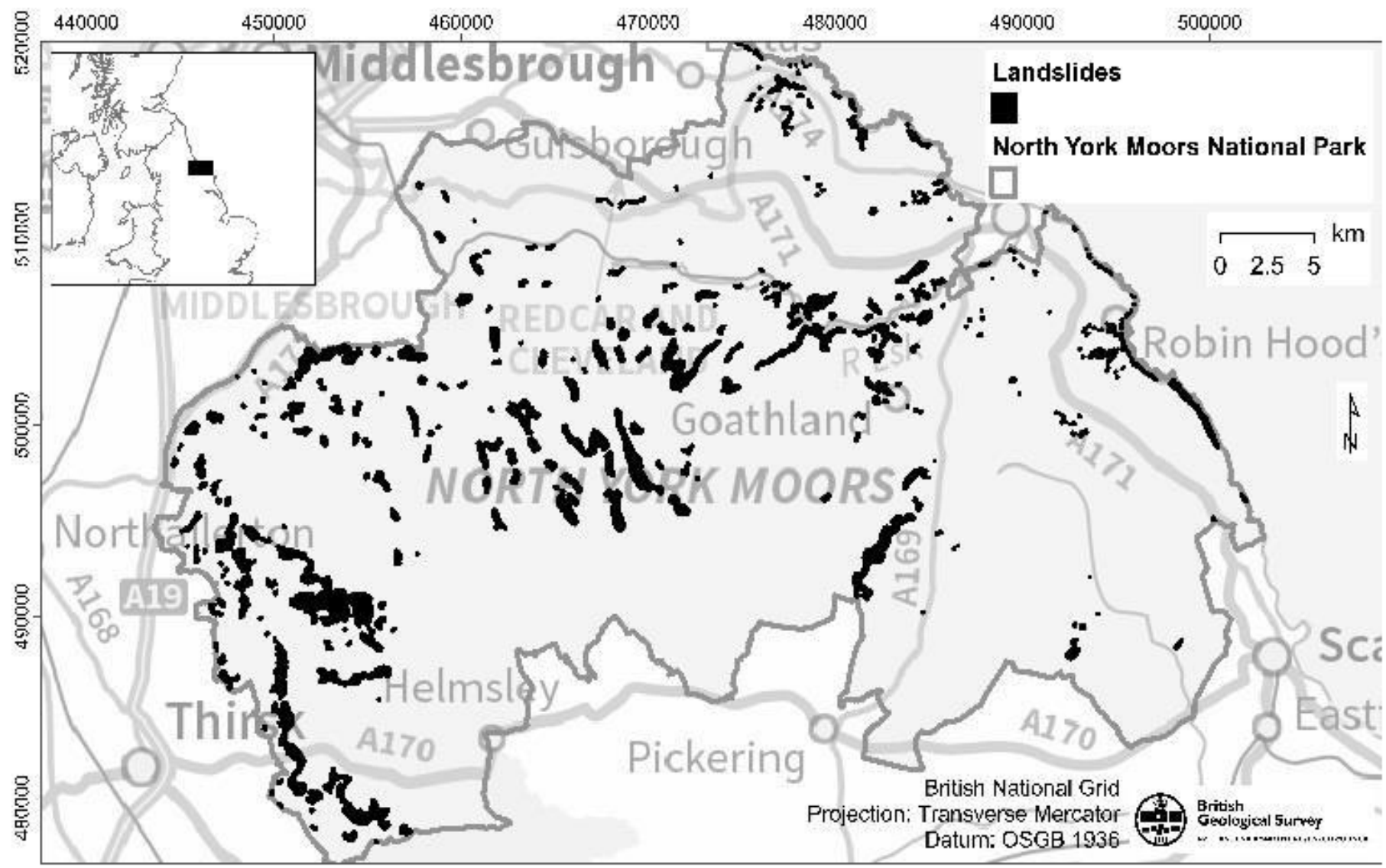

Figure 2. Landslide distribution in the North York Moors National Park. Contains Ordnance Survey data (C Crown Copyright and database rights 2015 .

Landslides are not spread evenly throughout the geomorphological zones. Instead, clustering is evident in areas with steep gradients: typically on valley sides in the High Moors; coastal cliffs; escarpment edges and incised valleys in the Tabular and Hambleton Hills area and; in steeply incised valleys within the Cleveland Hills zone. Landslide size varies significantly with the largest landslide covering $3.6 \mathrm{~km}^{2}$, the smallest $57 \mathrm{~m}^{2}$ and average landslide area equalling $0.08 \mathrm{~km}^{2}$. The landslide size frequency distribution is significantly skewed towards smaller events (standard deviation of $0.24 \mathrm{~km}^{2}$ ).

Table 2. Landslide number and area by geomorphological zone

\begin{tabular}{|c|c|c|}
\hline $\begin{array}{l}\text { Geomorphological } \\
\text { Zone }\end{array}$ & $\begin{array}{l}\text { Landslide count } \\
\text { (\% of study area } \\
\text { total) }\end{array}$ & $\begin{array}{l}\text { Landslide area } \\
\text { (\% of study area } \\
\text { total) }\end{array}$ \\
\hline $\begin{array}{l}\text { High Moors (including } \\
\text { River Esk Valley) }\end{array}$ & 42.1 & 52.0 \\
\hline Cleveland Hills & 7.3 & 0.9 \\
\hline $\begin{array}{ll}\text { Tabular } & \text { and } \\
\text { Hambleton Hills } & \end{array}$ & 26.9 & 41.6 \\
\hline Coast & 23.6 & 5.4 \\
\hline
\end{tabular}

Eight different types of landslide are evident: translational slides, rotational slides, slides (undifferentiated), slumps, topples, flows, falls and unknown. These types also occur as single, successive or multiple features within the same landslide. The most frequently occurring landslide type is translational slides (17.8\%), followed by rotational slides (8.8\%) (Figure 3). The most infrequent landslide type is toppling with only 1 such failure occurring in the study area. The large proportion of landslides of unknown type (62.9\%) is largely due to earlier BGS mapping data in the Northallerton and Pickering areas of the National Park incorporated into the database. $9.4 \%$ of landslides include more than one type, for example translational slides degrading to flows downslope or rotational slides with falls at the backscarp. 


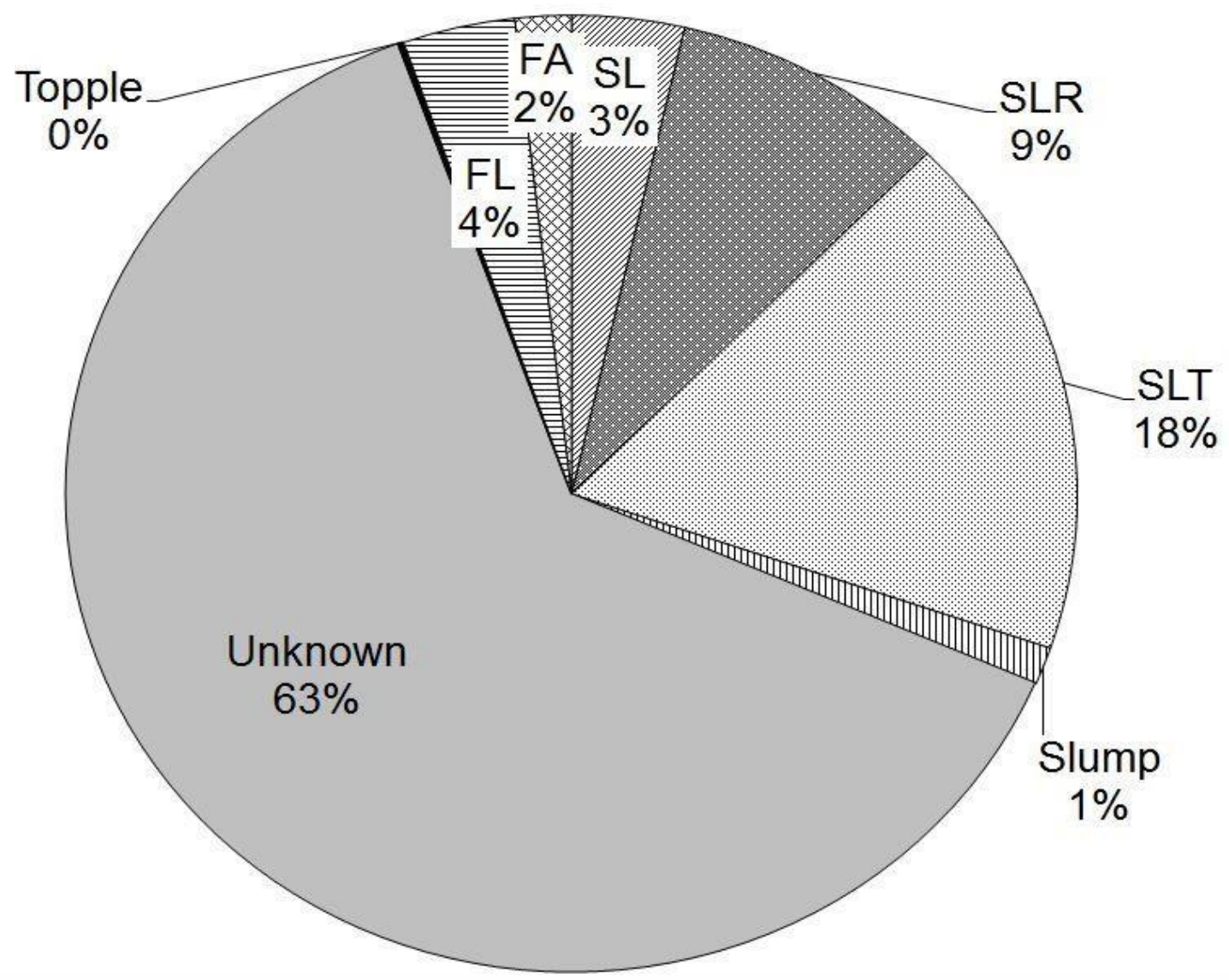

Figure 3. Landslide types in the North York Moors National Park. FL= Flow, FA= Fall, SL= Slide (undifferentiated), SLR= Slide Rotational, SLT= Slide Translational.

In order to identify potential pre-conditioning and triggering factors the geology, elevation, slope, and aspect characteristics of the mapped landslides were examined along with proximity to the coast and water courses. The geological characteristics of the landslides were interrogated in 3 different ways: 1) by calculating the areas of the different bedrock and superficial lithologies affected by landslides across the National Park as a whole; 2) by attributing each individual landslide polygon with the most significant lithology (i.e. covering the greatest area of the polygon) and; 3) by repeating the second step but only for landslides where the most significant lithology covers $90 \%$ or more of the landslide area. Methods 1 and 2 are based on the whole landslide inventory for the study area (556 landslides) whilst method 3 relies on a reduced number of 329 landslides which meet the criteria for the main bedrock attribute accounting for $>90 \%$ of landslide area. As the most significant contributor to the mapped landslide area may not always be the lithology in which the landslide initiates, this combination of approaches captures more accurately the landslide-prone lithologies in the National Park.

The bedrock geological characteristics of the mapped landslides are presented in Table 3 . The different methods reveal similar findings for the most failure-affected bedrock lithologies in the study area. The Whitby Mudstone Formation is the most failed lithology, followed either by the Long Nab Member of the Scalby Formation or the Saltwick Formation \& Cloughton Formation (undifferentiated) and thirdly by the Redcar Mudstone Formation. In each case the percentages presented are similar. The least landslide-affected bedrock lithologies are more variable across the 3 methods. By their very nature these are likely to be less statistically significant as a result of the few landslides involved in these calculations. This may account, in part, for the inclusion of the Mulgrave Shale Member of Whitby Mudstone Formation as one of least affected lithologies under method 2. Alternatively, the relatively stronger nature of this jet-bearing member may explain a much lower landslide incidence than that seen in the Whitby Mudstone Formation as a whole. 
Table 3. Bedrock geological characteristics of mapped landslides. Note only the three most and least representative lithologies are reported. Formation codes as in Table 1. 1- percentage of total landslide area; 2- percentage of total landslide number; 3- percentage of total landslide number where the main lithology provid es $>90 \%$ of individual landslide area.

\begin{tabular}{|c|c|c|c|c|c|}
\hline \multicolumn{6}{|c|}{ Method } \\
\hline 1 & & 2 & & 3 & \\
\hline Lithology & $\%$ & Lithology & $\%$ & Lithology & $\%$ \\
\hline WHM & 36.6 & WHM & 38.1 & WHM & 34.3 \\
\hline $\begin{array}{l}\text { Long Nab } \\
\text { Member, } \\
\text { SCY }\end{array}$ & 21.1 & $\begin{array}{l}\text { Long Nab } \\
\text { Member, } \\
\text { SCY }\end{array}$ & 11.3 & $\begin{array}{l}\text { SWK, CLF } \\
\text { (undifferentiated) }\end{array}$ & 13.4 \\
\hline RMU & 6.8 & RMU & 10.3 & RMU & 12.8 \\
\hline $\begin{array}{l}\text { Gristhorpe } \\
\text { Member, } \\
\text { CLH }\end{array}$ & 0.06 & $\mathrm{CB}$ & 0.18 & DGR & 0.3 \\
\hline $\begin{array}{l}\text { Yedmandale } \\
\text { Member, } \\
\text { COO }\end{array}$ & 0.006 & CBCA & 0.18 & EBB & 0.3 \\
\hline UCG & 0.001 & $\begin{array}{l}\text { Mulgrave } \\
\text { Shale } \\
\text { Member, } \\
\text { WHM }\end{array}$ & 0.18 & SCR & 0.3 \\
\hline
\end{tabular}

Interestingly, the Oxford Clay Formation, which is landslide-prone in other areas of the country (for example along the Dorset coast, Reeves et al. 2006), appears less so in the North York Moors area, accounting for only $4 \%$ of the landslides (on average across the 3 methodologies). This may be due in part to the fact that the Oxford Clay Formation is not particularly prevalent in the study area (occurring across $1.9 \%$ of the total area). However, when examining these relationships it appears that the correlation is rather poor with $\mathrm{R}^{2}$ values of 0.4, 0.2 and 0.3 respectively for the three methods. This suggests that other factors are responsible for the low landslide occurrence in deposits of the Oxford Clay Formation in the study area. Slope angle is likely to be accountable with the mean slope angle of 18 degrees experienced by deposits of the Oxford Clay Formation in the study area potentially falling below the failure-triggering threshold.

Only $13.5 \%$ of the area affected by landslides in the National Park has superficial deposits mapped. However, $56.3 \%$ of the 556 landslides mapped have superficial deposits mapped in the area of the landslide polygon. This does not necessarily mean that the failure initiated in superficial deposits, but implies that superficial lithologies may be significant in pre-conditioning failure. For each of the 3 methodologies above, the most affected superficial lithology is the Devensian Till (60.9, 63.3 and 85.9\%, respectively). As with the bedrock deposits, the least landslide-affected lithology is more variable: Devensian Glaciofluvial Sheet Deposits $(0.0001 \%)$; Lacustrine Deposits $(0.32 \%)$ and alluvium (1.2\%), respectively. Note that methods 1 and 2 are based on a sample size of 313 landslides whilst method 3 relies on 170 landslides which meet the criteria for the main superficial attribute accounting for $>90 \%$ of landslide area.

For all landslide types, the most frequently occurring lithology is the Whitby Mudstone Formation, with the exception of slumps that are predominantly characterised by the Cleveland Ironstone Formation \& Saltwick Formation (undifferentiated). The associated superficial deposit for each of these landslides is the Devensian till. It is therefore possible to conclude that the Whitby Mudstone Formation is the most failure-prone geology in the area. Unusually, the Whitby Mudstone Formation appears to form the major component in falls and topples. This may be due to failures of this type in the more competent beds within the formation. However, it is more likely to be an artefact of the data as a) landslide type in this case has been categorised by the most prominent type, i.e. that affecting the greatest proportion of the landslide area and b) only a few landslides, where topples and falls form the main failure mechanism, are present in the study area (1 topple and 10 falls) meaning that the sample size is unlikely to be statistically significant. 
The geomorphometry of the mapped landslides is summarised in Table 3. With the exception of falls and topples, all landslide types occur at elevations greater than $90 \mathrm{mOD}$. Slumps and topples occur at relatively low slope angles (11.1 and 6.3 degrees, respectively) whilst all other types occur on slopes greater than 14.5 degrees. The majority of landslide types possess a southerly component to their aspect with the exception of topples which face north east and falls and slumps east. It should be noted that the sample size for falls and topples is likely to be statistically insignificant. Of the 556 landslides mapped, 27 (4.9\%) occur along the coast (note that this is based on only the most coast-proximal portion of the Coast geomorphological zone) and $94(21.8 \%)$ have watercourses lying within $1 \mathrm{~m}$ of the landslide deposit.

Table 3. Geomorphometrical characteristics of mapped landslides. Note for aspect, North equals 0 degrees.

\begin{tabular}{lr}
\hline Item & \multicolumn{1}{c}{ Value } \\
\hline Mean landslide elevation & $150.5 \mathrm{mOD}$ \\
Lowest mean landslide elevation & $0.2 \mathrm{mOD}$ \\
Highest mean landslide elevation & $384.0 \mathrm{mOD}$ \\
Average mean slope angle & 15.2 degrees \\
Minimum mean slope angle & 2.2 degrees \\
Maximum mean slope angle & 52.3 degrees \\
Average median slope aspect & 174.5 degrees \\
Minimum median slope aspect & 4.7 degrees \\
Maximum median slope aspect & 351.4 degrees \\
\hline
\end{tabular}

\subsection{North York Moors National Park Landslide Case Studies}

In terms of landslide activity, two main forms of failure are evident: large-scale, deep-seated failures (often slides) and smaller-scale, shallow failures (typically earth flows and/or slides). The degree of degradation and geomorphology of the large-scale features suggest development under Pleistocene periglacial conditions. Very fresh, shallow features show that the processes responsible for triggering the smaller-magnitude landslides are still active. Case studies of the two major types are presented below.

\subsubsection{Mark Nab Landslide, Great Fryup Dale (NGR 471368, 502842)}

This is the largest $\left(360000 \mathrm{~m}^{2}\right.$ ) of a cluster of bedrock landslides distributed throughout the deep valleys of the High Moors geomorphological zone. The landslide lies on a largely north and easterly facing slope on the Jurassic Escarpment, which rises approximately $200 \mathrm{~m}$ over a distance of $600 \mathrm{~m}$ to an elevation of c. $349 \mathrm{mOD}$ (Figure 4). The landslide comprises a complex of deep-seated rotational slides (maximum rupture depth of 50 $\mathrm{m}$ ) with deposits of the Saltwick Formation capping rotated blocks of the Whitby Mudstone Formation (Boon et al. 2015b).

Downslope these degrade to progressively shallower flows in the Whitby Mudstone Formation (Figure 4). Mean slope angle in the central section of the slide body is 15.0 degrees with a maximum of 44.6 degrees present towards the backscarp. Detailed geomorphological and geological mapping of this section in 2010 and 2011 revealed that the mode of failure is strongly controlled by lithology, joint pattern, and rate of lateral unloading. Geophysical surveys and radio carbon dating suggest that the frontal mudflow complex was last active in the late Holocene (post c.2270 \pm 30 years BP) (Boon et al. 2015a, Boon et al. 2015b). Preservation of ridge and furrow plough lines suggests that the main landslide body has not been active in historic times. Very recent activity is limited to small-scale translational debris and mudslides in colluvium and slipped weathered or disturbed mudstone on stream banks and on the main backscarp and minor rockfalls from the sandstone beds exposed along the main escarpment cliff. This and similar slopes are prone to becoming unstable again under future wetter climates (Boon et al. 2015a). 

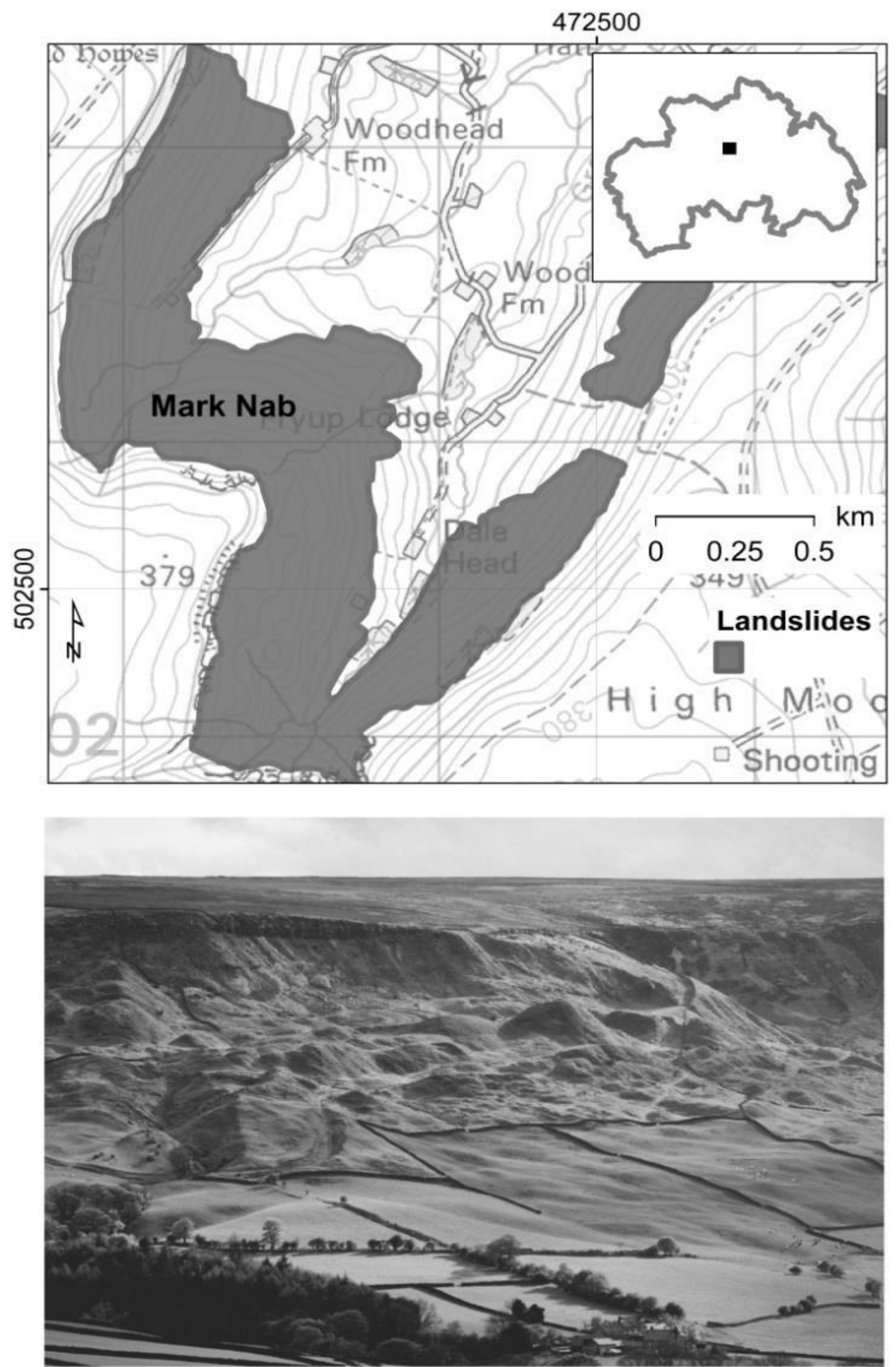

Figure 4. The Mark Nab landslide in the North York Moors National Park. Contains Ordnance Survey data @ Crown Copyright and database rights 2015 .

\subsubsection{Rhumbard Snout, Levisham, Newton Dale (NGR 481893, 491330)}

Mapped in 2010, this small $\left(5626.4 \mathrm{~m}^{2}\right)$ landslide lies in a shallow south-easterly facing valley near Levisham Station (Figure 5). This shallow, single, translational slide fails across deposits of the Osgodby Formation, 
Cornbrash Formation and Long Nab Member of the Scalby Formation. No superficial deposits are mapped in the area. Failure is likely to have initiated in the Cornbrash Formation and is triggered in part by stream undercutting combined with high pore-water pressures in the landslide body. Indeed, water was issuing from the landslide body at the time of mapping and a roadside drain terminates in the area. A maximum elevation of $111.6 \mathrm{mOD}$ is achieved at the landslide backscarp decreasing to $84.4 \mathrm{mOD}$ at the toe. Mean slope angles of 12.6 degrees are present. The landslide is active and at the time of surveying was causing ongoing damage to the road to Levisham Station and multiple, recent road repairs are evident.
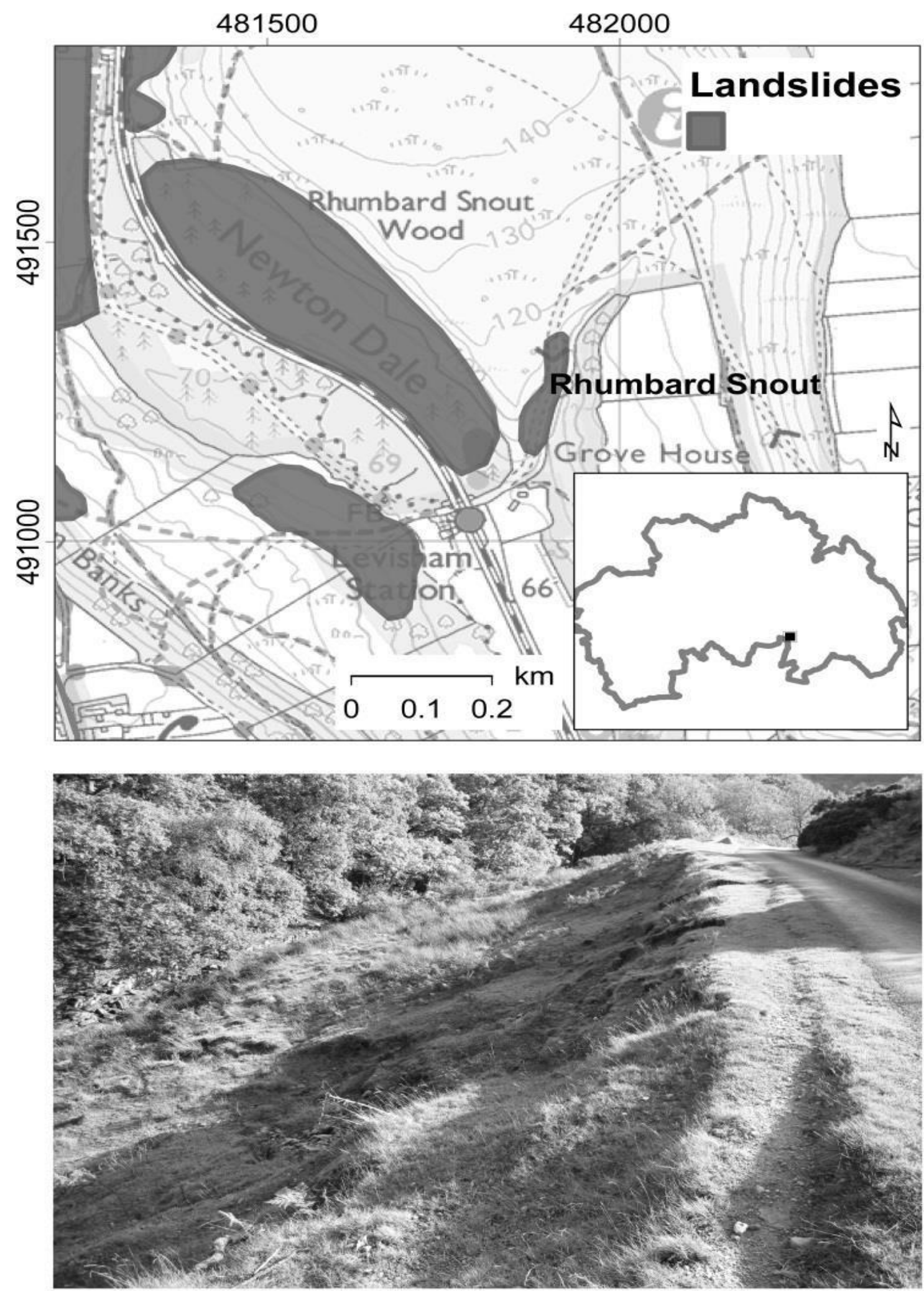

Figure 5. The Rhumbard Snout landslide in the North York Moors National Park. Contains Ordnance Survey data C Crown Copyright and database rights 2015 . 


\subsection{North York Moors National Park Landslide Domains}

The North York Moors National Park landslide map and inventory have been used to inform the NLDM. This map, which is currently under development, adopts a land systems mapping approach and contributes to the National Landslide Susceptibility Map and the NGA (Dijkstra et al. 2015). The development of a series of hierarchical landslide domains allows hazard assessment by underpinning threshold modelling to determine how different types of landslides and terrains are affected by hydrometeorological conditions (Pennington et al. 2014). The NLD, which the current study updates, was used as a starting point to identify landslide clusters and characteristics (Hurst et al. 2013, Pennington et al. 2015). Landslide domains provide information on large-scale landsliding patterns and the influence of strata whilst sub-domains recognise additional geological and geomorphological drivers. The North York Moors landslide map has allowed the delineation of 2 domains and 3 sub-domains in the North York Moors National Park (Figure 6). Domain A is characterised by deepseated, bedrock rotational slides and associated flows in the high moors area of the National Park. Domains B and $\mathrm{C}$ are typified by small, shallow slides occurring in glaciallysteepened slopes (B) and modern river valleys (B and C). Please note that at present the NLDM is predominantly derived from inland landslide characteristics.

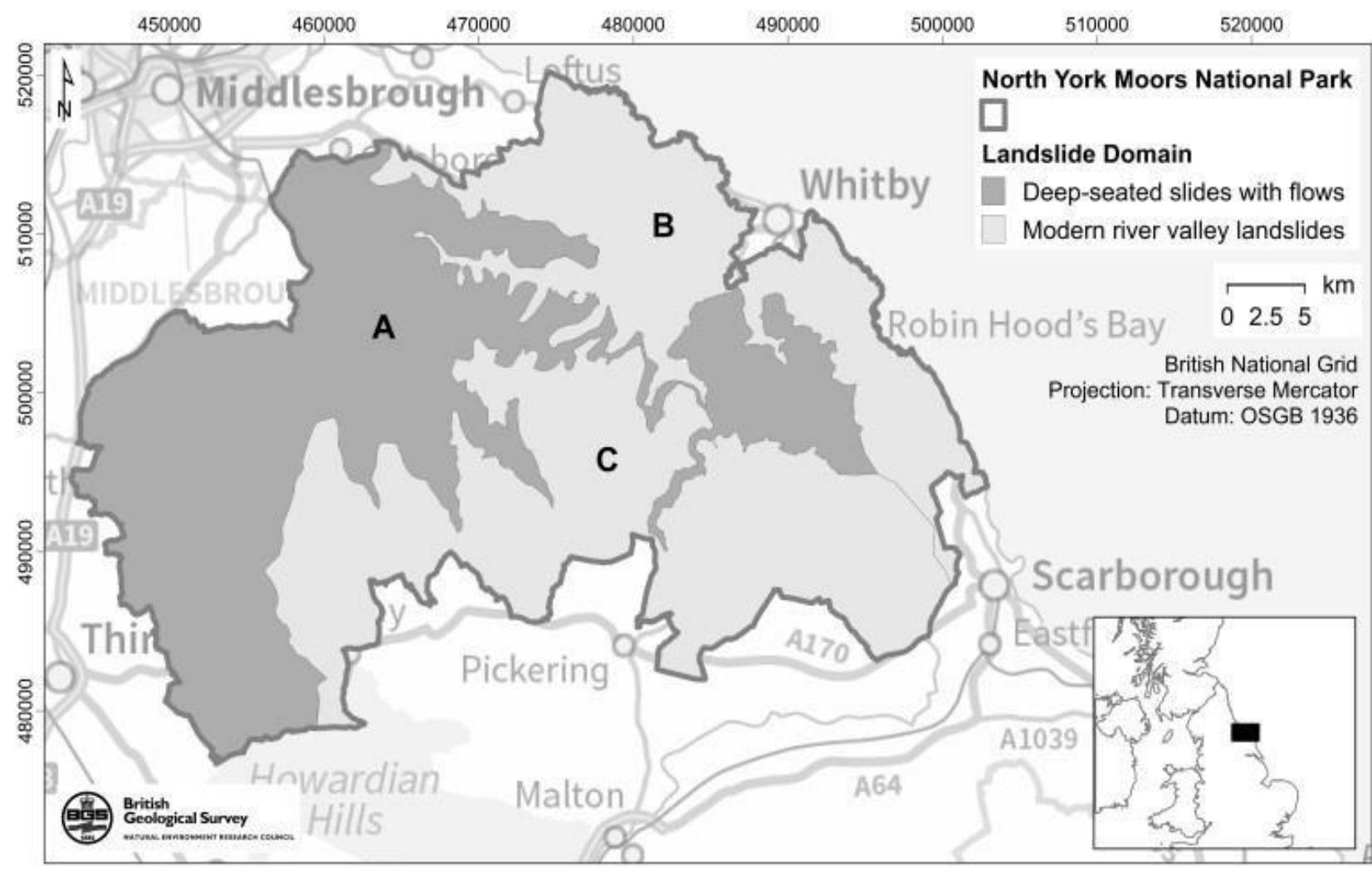

Figure 6. Landslide domains in the North York Moors National Park. Contains Ordnance Survey data (C) Crown Copyright and database rights 2015 .

\subsection{National Geohazard Assessment}

BGS GeoSure assesses landslide susceptibility in Great Britain at a scale of 1:50 000, providing an A (low susceptibility) to E (high susceptibility) score. An additive algorithm generates a score from factors influencing slope stability including slope, lithology (including strength and permeability characteristics) and bedrock discontinuities (Foster \& Diaz-Doce 2010, Booth et al. 2010, Harrison et al. 2011, Dashwood et al. 2014). The North York Moors landslide map, and the NLD it informs, are used to ground truth and interpret the data. GeoSure is known to perform well in inland areas and in certain coastal locations but less so in other areas (Wildman \& Hobbs 2005, Foster 2008). Comparison of the North York Moors National Park landslide map and BGS GeoSure supports this (Figure 7) and provides further target sites for development of an improved National Landslide Susceptibility Map (Jordan et al. 2013). 

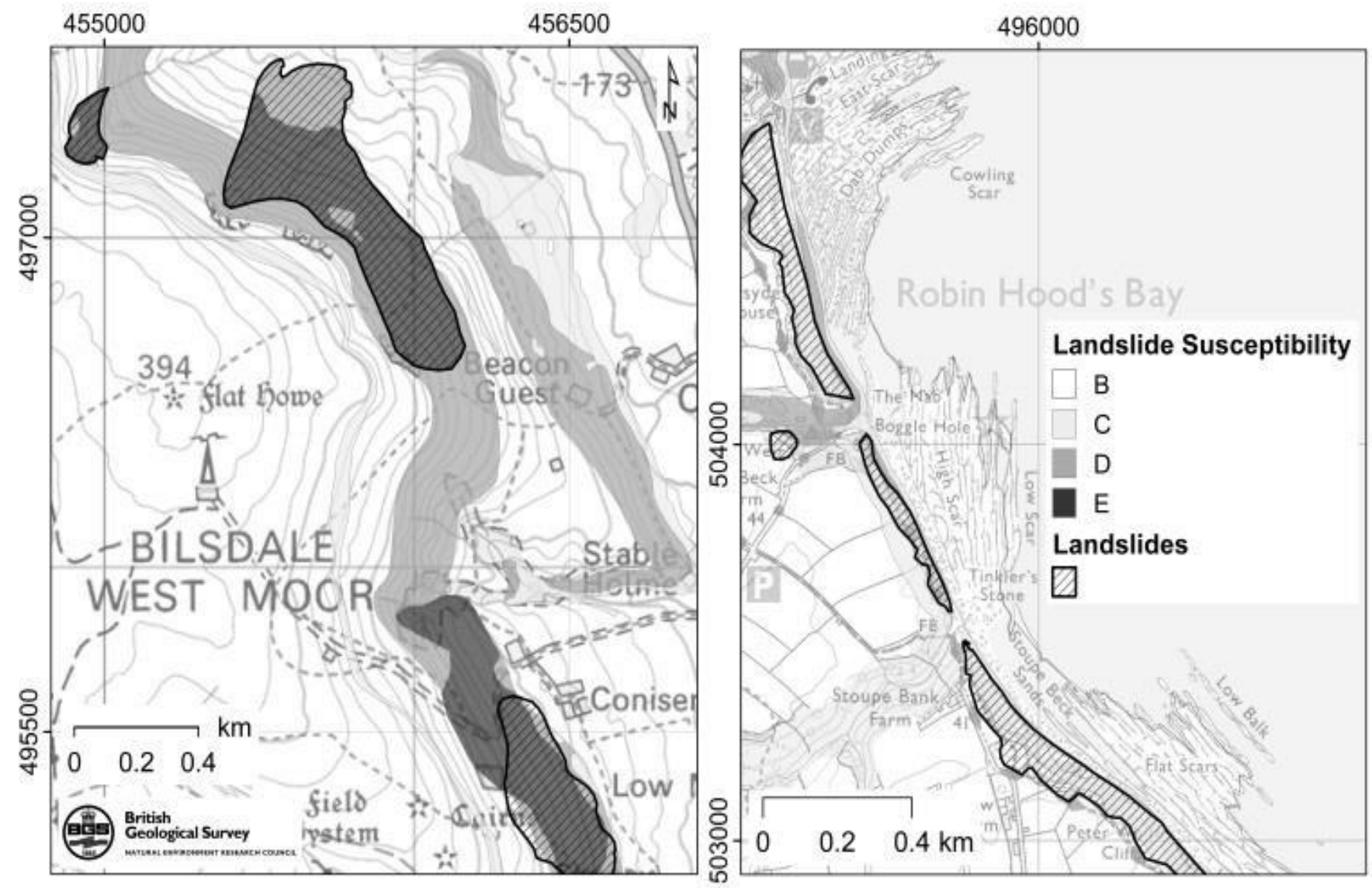

Figure 7. BGS GeoSure landslide susceptibility and mapped landslides for selected areas of the North York Moors National Park. Contains Ordnance Survey data C Crown Copyright and database rights 2015.

\section{CONCLUSION}

A high population density, abundance of relict landslides and high proportion of failure susceptible lithologies make landslide research in the UK paramount. The BGS has developed a novel, multi-stage methodology for landslide mapping using new technologies combined with traditional mapping techniques. This methodology has most recently been applied to the $1441 \mathrm{~km}^{2}$ North York Moors National Park in northern England and an inventory of 556 landslides developed. By examining the characteristics of these landslides failure-susceptible lithologies and landslide mechanisms have been identified. The Whitby Mudstone Formation is the most failureprone bedrock lithology in the area and Devensian Till the most landslide-affected superficial lithology. Unusually, areas with deposits of Oxford Clay Formation appear relatively stable in the National Park: a condition that is likely to result, at least in part, from low slope angles in the vicinity of these deposits. Two major contrasting types of failure are evident: large-scale, deep-seated, dormant slides and smaller-scale, shallow, active flows and slides. Detailed case studies of these are presented, highlighting differences in the nature of the hazard they present. The North York Moors landslide map and inventory has important implications for landslide hazard assessment and susceptibility modelling and has been used to inform the BGS National Landslide Database, the National Landslide Domains Map and the National Geohazard Assessment.

\section{ACKNOWLEDGEMENTS}

This paper is published with the permission of the Executive Director of the British Geological Survey (NERC). The authors are very grateful to Vanessa Banks (BGS) for her constructive comments and assistance with the drafting of this paper. 


\section{REFERENCES}

Boon, D., Chambers, J., Wilby, P., \& Grebby, S. 2015a. Characterising landslide processes using combined remote sensing and geophysical surveying approach: examples from north east England, UK. Geophysical Research Abstracts, 17.

Boon, D., Chambers, J., Hobbs, P., Kirkham, M., Merritt, A., Dashwood, C., Pennington, C., \& Wilby, P. 2015b. A combined geomorphological and geophysical approach to characterising relict landslide hazard on the Jurassic Escarpments of Great Britain. Geomorphology, 248: 296-310.

Booth, K., Diaz-Doce, D., Harrison, M., \& Wildman, G. 2010. User guide for the British Geological Survey GeoSure dataset. OR/10/066. British Geological Survey, Nottingham, UK. 17pp.

BGS (British Geological Survey). 1992. BGS 1:50 000 Geological Map Sheet 43 (Solid and Drift).

BGS (British Geological Survey). 1998. BGS 1:50 000 Geological Map Sheet 54 (Solid and Drift).

Dashwood, C., Diaz Doce, D., \& Lee, K. 2014. GeoSure Version 7 Methodology: Landslides Slope Instability. IR/14/014. British Geological Survey, Nottingham, UK. 31pp.

Dijkstra, T., Jenkins, G., Freeborough, K., Parry, S., Wathall, S., \& Ward, E. 2015. Landslide domain statistics and impact libraries; a report on GO-Science funded activity 20142015. OR/15/049. British Geological Survey, Nottingham, UK. 32pp.

Evans, H., Pennington, C., Jordan, C., \& Foster, C. 2013. Mapping a nation's landslides: a novel multi-stage methodology. In: Margottini, C., Canuti, P., \& Sassa, K. (Eds.), Landslide Science and Practice: Landslide Science and Practice 1. Springer-Verlag, Berlin, Germany: 21-27.

Foster, C. 2008. Methodology report for the development of a tool to collect data on coastal instability. IR/09/008. British Geological Survey, Nottingham, UK. 17pp.

Foster, C., \& Diaz Doce, D. 2010. GeoSure Version 6 Methodology: Landslides (Slope Instability). IR/10/091. British Geological Survey, Nottingham, UK. 34pp.

Foster, C., Harrison, M., \& Reeves, H.J. 2011. Standards and methods of hazard assessment for mass movements in Great Britain. Journal for Torrent and Avalanche Control. 166.

Foster, C., Pennington, C., Culshaw, M., \& Lawrie, K. 2012. The National Landslide Database of Great Britain: development, evolution and applications. Environmental Earth Science, 663: 941-953.

Gibson, A., Culshaw, M., Dashwood, C., \& Pennington, C. 2013. Landslide management in the UK-the problem of managing hazards in a 'low-risk' environment. Landslides, 20: 599-610.

Günther, A., Van Den Eeckhaut, M., Reichenbach, P., Hervás, J., Malet, J.-P., Foster, C., \& Guzzetti, F. 2013. New developments in harmonized landslide susceptibility mapping over Europe in the framework of the European Soil Thematic Strategy. In: Margottini, C., Canuti, P., \& Sassa, K. (Eds.), Landslide Science and Practice: Landslide Science and Practice 1. Springer-Verlag, Berlin, Germany: 297301.

Harrison, M., Foster, C., Gibson, A., Cooper, R., \& Wildman, G. 2011. GeoSure Version 5. Methodology Review. Slope Instability. IR/08/093. British Geological Survey, Nottingham, UK.

Hurst, M., Ellis, M., Royse, K., Lee, K., \& Freeborough, K. 2013. Controls on the magnitude-frequency scaling of an inventory of secular landslides. Earth Surface Dynamics, 1: 67-78.

Jordan, H., Hobbs, P., Westhead, K., Dashwood, C., Jones, L., Thorpe, S., \& Cartwright, C. 2013. NERC Environmental Data Short Project: Development of a coastal cliff instability susceptibility tools. OR/13/044. British Geological Survey, Nottingham, 103pp.

Pennington, C., Dijkstra, T., Lark, M., Dashwood, C., Harrison, A., \& Freeborough, K. 2014. Antecedent Precipitation as a Potential Proxy for Landslide Incidence in South West United Kingdom. In: Landslide Science for a Safer Geoenvironment. SpringerVerlag, Berlin, Germany: 253-259.

Pennington, C., \& Harrison, A. 2013. 2012 - a landslide year? GeoScientist magazine. Geological Society of London, 23: 10-15.

Pennington, C., Freeborough, K., Dashwood, C., Dijkstra, T., \& Lawrie, K. 2015. The National Landslide Database of Great Britain: Acquisition, communication and the role of social media. Geomorphology, 249, 44-51.

Reeves, G. M., Sims, I., \& Cripps, J. C. (Eds.) 2006. Clay materials used in construction. Geological Society Engineering Geology Special Publication, 21. Geological Society, London.

Van Den Eeckhaut, M., \& Hervás, J. 2012. Landslide inventories in Europe and policy recommendations for their interoperability and harmonization. A JRC contribution to the EU-FP7 SafeLand project. ISBN 978-92-79-27994-2.

Wildman, G., \& Hobbs, P. 2005. GENI- Scoping study for coastal instability hazard susceptibility - Filey Bay, Beachy Head and Lyme Bay. IR/05/018. British Geological Survey, Nottingham. 20pp. 